\title{
ADDITIONAL ARTICLES ABSTRACTED IN ACP JOURNAL CLUB
}

The following articles are abstracted in the March/April 2002 issue of ACP Journal Club. The declarative title of each abstract as published in APC Journal Club precedes the article citation.

\section{Therapeutics}

Review: platelet glycoprotein IIb/IIIa blockers for PCI or acute coronary syndromes reduce death and MI but increase bleeding Bosch X, Marrugat J. Platelet glycoprotein Ilb/IIIa blockers for percutaneous coronary revascularization, and unstable angina and non-ST-segment elevation myocardial infarction. Cochrane Database Syst Rev 2001;(4):CD002130 (latest version 24 Aug 2001).

Abciximab did not reduce death or myocardial infarction in the acute coronary syndrome without early revascularization

The GUSTO IV-ACS Investigators. Effect of glycoprotein IIb/ IIIa receptor blocker abciximab on outcome in patients with acute coronary syndromes without early coronary revascularisation: the GUSTO IV-ACS randomised trial. Lancet 2001 Jun 16;357:1915-24.

Tenecteplase plus enoxaparin or abciximab was better than tenecteplase plus unfractionated heparin for acute MI

The Assessment of the Safety and Efficacy of a New Thrombolytic Regimen (ASSENT)-3 Investigators. Efficacy and safety of tenecteplase in combination with enoxaparin, abciximab, or unfractionated heparin: the ASSENT-3 randomised trial in acute myocardial infarction. Lancet 2001 Aug 25;358:605-13.

Reteplase plus abciximab and reteplase alone led to similar 30-day mortality rates in acute MI

The GUSTO V Investigators. Reperfusion therapy for acute myocardial infarction with fibrinolytic therapy or combination reduced fibrinolytic therapy and platelet glycoprotein $\mathrm{Ilb} / \mathrm{III}$ inhibition: the GUSTO V randomised trial. Lancet 2001 Jun 16;357:1905-14.

Prone positioning for acute respiratory failure improved shortterm oxygenation but not survival

Gattinoni L, Tognoni G, Presenti A, et al, for the Prone-Supine Study Group. Effect of prone positioning on the survival of patients with acute respiratory failure. $N$ Engl J Med 2001 Aug 23;345:568-73.

Itraconazole was as effective as amphotericin B for fever and neutropenia in cancer and led to fewer adverse events

Boogaerts M, Winston DJ, Bow EJ, et al, and the Itraconazole Neutropenia Study Group. Intravenous and oral itraconazole versus intravenous amphotericin B deoxycholate as empirical antifungal therapy for persistent fever in neutropenic patients with cancer who are receiving broad-spectrum antibacterial therapy. A randomized, controlled trial. Ann Intern Med 2001 Sep 18;135:412-22.
Single-dose doxycycline prevented Lyme disease after an Ixodes scapularis tick bite

Nadelman RB, Nowakowski J, Fish D, et al, for the Tick Bite Study Group. Prophylaxis with single-dose doxycycline for the prevention of Lyme disease after an Ixodes scapularis tick bite. N Engl J Med 2001 Jul 12;345:79-84.

Prolonged antibiotic treatment did not relieve chronic symptoms in Lyme disease

Klempner MS, Hu LT, Evans J, et al. Two controlled trials of antibiotic treatment in patients with persistent symptoms and a history of Lyme disease. N Engl J Med 2001 Jul 12;345:85-92.

A community support program for dementia delayed but did not reduce institutionalization over 2 years

Eloniemi-Sulkava U, Notkola IL, Hentinen M, et al. Effects of supporting community-living demented patients and their caregivers: a randomized trial. J Am Geriatr Soc 2001 Oct;49:1282-7.

Donepezil improved the clinical state and quality of life in moderate-to-severe Alzheimer disease

Feldman H, Gauthier S, Hecker J, et al, and the Donepezil MSAD Study Investigators Group. A 24-week, randomized, double-blind study of donepezil in moderate to severe Alzheimer's disease. Neurology 2001 Aug 28;57:613-20.

\section{Diagnosis}

Clinical and radiologic evaluation had moderate sensitivity and specificity for detecting idiopathic pulmonary fibrosis

Hunninghake GW, Zimmerman MB, Schwartz DA, et al. Utility of a lung biopsy for the diagnosis of idiopathic pulmonary fibrosis. Am J Respir Crit Care Med 2001 Jul 15;164:193-6.

\section{Quality improvement}

Rule-based computerized reminders increased ordering of preventive services in an inpatient setting

Dexter PR, Perkins S, Overhage JM, et al. A computerized reminder system to increase the use of preventive care for hospitalized patients. $N$ Engl J Med 2001 Sep 27;345:965-70.

\section{Clinical prediction guide}

The TIMI risk score predicted mortality in patients with ST-elevation myocardial infarction

Morrow DA, Antman EM, Parsons L, et al. Application of the TIMI risk score for ST-elevation MI in the National Registry of Myocardial Infarction 3. JAMA 2001 Sep 19;286:1356-9. 